\title{
Oxidative Destruction of Vulcanized by Changing the Dispersion Composition of Oxidized Vulcanized
}

\author{
Milen Dimova* and Zhuldyz Smailovab \\ aTrakia University \\ Yambol, Bulgaria \\ ${ }^{b}$ Kyzylorda University named after Korkyt Ata \\ Kyzylorda, Kazakhstan
}

Received 05.11.2020, received in revised form 23.01.2021, accepted 21.03.2021

\begin{abstract}
The aim of the present work is to study the processes of oxidative destruction of waste vulcanizates (flakes) with nitric acid. The composition of the particles of the main reaction product was determined (oxidized vulcanized). The IR spectra of hexane and acetone extracts of the oxidized vulcanizates are also presented. It was found that the rubber component of the vulcanizates undergoes deep structural changes leading to the formation of products characterized by chemical heterogeneity.
\end{abstract}

Keywords: rubber chunks, coal, oxidative destruction, nitric acid.

Citation: Dimov M., Smailova Z. Oxidative destruction of vulcanized by changing the dispersion composition of oxidized vulcanized, J. Sib. Fed. Univ. Eng. \& Technol., 2021, 14(2), 207-214. DOI: 10.17516/1999-494X-0301

(C) Siberian Federal University. All rights reserved

This work is licensed under a Creative Commons Attribution-Non Commercial 4.0 International License (CC BY-NC 4.0).

* Corresponding author E-mail address: milen.dimov@trakia-uni.bg 


\title{
Окислительное разрушение вулканизатов \\ при изменении дисперсионного состава \\ окисленного вулканизата
}

\author{
Милен Димова ${ }^{a}$ Жулдыз Смаилова \\ ${ }^{a}$ Университет Тракия \\ Болгария, Ямбол \\ ${ }^{6}$ Кызылординский университет им. Корктыт Ата \\ Казахстан, Кьзылорда
}

\begin{abstract}
Аннотация. Целью данной работы является изучение процессов окислительной деструкции устаревших вулканизатов азотной кислотой. Определен состав частиц основного продукта реакции (окисленный вулканизат). Также представлены ИК-спектры гексанового и ацетонового экстракта из окисленного вулканизата. Было обнаружено, что каучуковый компонент вулканизатов терпит глубокие структурные изменения, приводящие к получению продуктов, характеризующихся химической неоднородностью.
\end{abstract}

Ключевые слова: пласты резины, уголь, окислительное деструкция, азотная кислота.

Цитирование: Димов, Милен. Окислительное разрушение вулканизатов при изменении дисперсионного состава окисленного вулканизата / Милен Димов, Жулдыз Смаилова // Журн. Сиб. федер. ун-та. Техника и технологии, 2021, 14(2). C. 207-214. DOI: 10.17516/1999-494X-0301

\section{Introduction}

The ability of a macromolecule to take part in various reactions (chemical, electro- and photochemical, mechanical, thermal) facilitated the development of a number of research directions related to their application. One of these directions is the no-waste chemical technology with further recovery, modification or utilization to different extents the polymers after their initial use. In this respect, one method for utilization of the waste polymers is the preparation of new products from them by their interaction with nitric acid [1-3].

It has been found that nitrating, oxidative and destructive processes occur by the interaction of polymers with nitric acid which, depending on reaction conditions, produce polyfunctional products (PFP) and low molecular weight compounds (LMWC) with different yields [4-6].

In all cases of interaction of vulcanizate with nitric acid, the main product obtained is oxidized vulcanizate which is a mixture of polyfunctional organic products and technical charcoal (carbon black). The low molecular weight organic acids remain in the nitric acid solution and can be extracted from there at yields about $10 \%[7-11]$.

\section{Experimental}

The aim of the present work is to obtain information about the oxidation-reduction processes by studying the dispersion composition of the oxidized vulcanizates (OV).

It can be assumed that the relative decrease of the particle size during the interaction results from the destructive processes taking place while their agglomeration - to the structuring processes. The studies of these two processes was carried out indirectly by varying the mass of the equal sized 
particles, the two fractions of OV obtained by interaction of nitric acid with three frations of flakes from waste automobile tyres.

Fig. 1 shows the mass of the three summary OV fractions depending on the duration of the interaction. It can be seen from the figure that the masses of all the three fractions continuously decreased as a result of the destructive processes taking place which give low molecular weight products.

Fig. 2 shows three fractions of oxidized vulcanizate obtained by oxidizing initial fraction of flakes sized $0.80-0.63 \mathrm{~mm}$ depending on the duration of the oxidation. Curve 1 in the figure illustrates the total reduction of the mass of OV fraction up to $0.80 \mathrm{~mm}$, curve $2-\mathrm{OV}$ fraction with particle size $0.80-0.63 \mathrm{~mm}$ and curve $3-\mathrm{OV}$ fraction with particle size smaller than $0.63 \mathrm{~mm}$. As can be seen from Fig. 2, as early as the first $5 \mathrm{~min}$ the amount of fraction $0.80-0.63 \mathrm{~mm}$ decreased from $100 \%$ to $27 \%$. At the same time, the amount of the fraction with particle size smaller than $0.63 \mathrm{~mm}$ increased from $0 \%$ to $53 \%$. During the next $30 \mathrm{~min}$, the amount of fraction $0.80-0.63 \mathrm{~mm}$ (curve 2) sharply increased

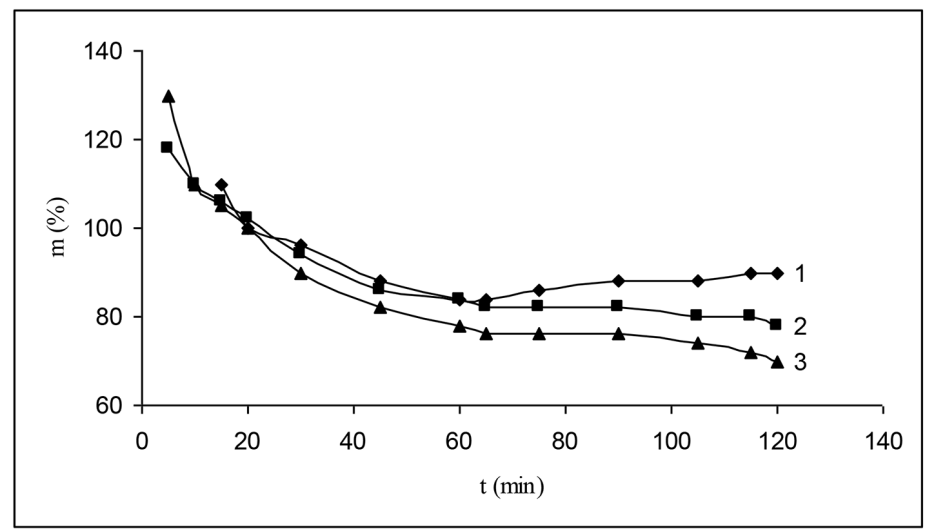

Fig. 1. Amount of oxidized vulcanizate (OV) depending on the oxidation duration of waste tyre flakes at ratio 1:40 mass parts and temperature $60^{\circ} \mathrm{C}$. Curve 1 - fraction $0.80-0.63 \mathrm{~mm}$; Curve 2 - fraction $0.50-0.40 \mathrm{~mm}$; Curve 3 - fraction $0.40-0.25 \mathrm{~mm}$

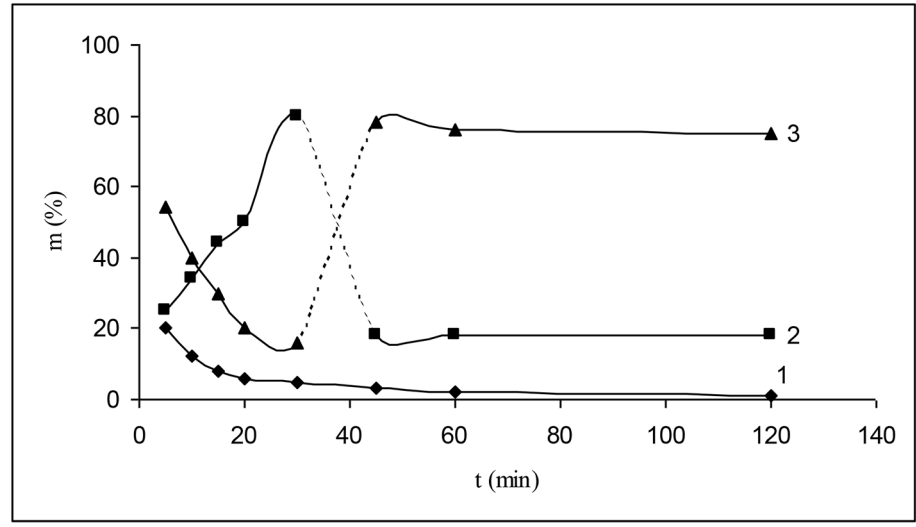

Fig. 2. Change of the dispersion composition of OV obtained after the interaction between OV flakes with nitric acid depending on the interaction duration. Curve 1 - OV fraction with size $1.00-0.80 \mathrm{~mm}$; Curve 2 - OV fraction with size $0.80-0.63 \mathrm{~mm}$; Curve $3-$ OV fraction with size smaller than $0.63 \mathrm{~mm}$ 
while the fraction with particle size smaller than $0.63 \mathrm{~mm}$ decreased. Based on these results, it can be assumed that during the first 5 min of interaction between the flakes and the nitric acid, the destructive processes predominate over the others which results in strong breakdown of the particles. Later on within 30 min the structuring processes begin to prevail and as a result the broken down particles obtain higher reaction area and agglomerate. For this reason, the fraction with particle size smaller than $0.63 \mathrm{~mm}$ decreased (curve 3 ) at the expense of fraction $0.80-0.63 \mathrm{~mm}$ (curve 2) which increased.

It should be noted that the initial decrease of fraction $0.80-0.63 \mathrm{~mm}$ during the first $5 \mathrm{~min}$ was due not only to the predominant destructive processes but also to the structuring processes which were weaker. They are manifested by the agglomeration of fraction $0.80-0.63 \mathrm{~mm}$ (curve 1). During the consequent $30 \mathrm{in}$, this fraction decreased because of the breaking down of th aggregates and it transforms into fraction $0.80-0.63 \mathrm{~mm}$.

At higher periods of interaction between the flakes and the nitric acid, the shapes of curves 2 and 3 drastically changed. The mass of fraction $0.80-0.63 \mathrm{~mm}$ sharply decreased (curve 2 ) while the fraction with particle size smaller than $0.63 \mathrm{~mm}$ sharply increased its mass. It can be assumed that internal volume interaction takes place in the aggregates forming fraction $0.80-0.63 \mathrm{~mm}$ after $30 \mathrm{~min}$, i.e. the destructive processes occur not only on aggregates' surface but also within them. As a result, new secondary breakdown takes place. Up to $120 \mathrm{~min}$ of the interaction between the flakes and the nitric acid, the fraction $0.80-0.63 \mathrm{~mm}$ (curve 2) and the fraction with particle size smaller than $0.63 \mathrm{~mm}$ (curve 3) did not change their mass.

Fig. 3 presents three fractions of oxidized vulvanizate obtained by interaction of fraction of flakes with particle size $0.50-0.40 \mathrm{~mm}$ with nitric acid depending on the interaction duration. The fractions had sizes up to $0.50 \mathrm{~mm}$ (curve 1), $0.50-0.40 \mathrm{~mm}$ (curve 2) and smaller than $0.40 \mathrm{~mm}$ (curve 3). It can be seen from the figure that the curves illustrating the change of the masses of the corresponding fractions have shapes similar to that shown in Fig. 2. Similarly, during the first $5 \mathrm{~min}$ of the interaction the mass of OV with particle size $0.50-0.40 \mathrm{~mm}$ decreased from $100 \%$ to $14 \%$. The masses of the fractions with particle size up to $0.50 \mathrm{~mm}$ and smaller than $0.40 \mathrm{~mm}$ was $50 \%$ andи $30 \%$, respectively. Curve 3 (Fig. 3) describing the destructive processes indicates that until $15^{\text {th }}$ minute of the interaction it

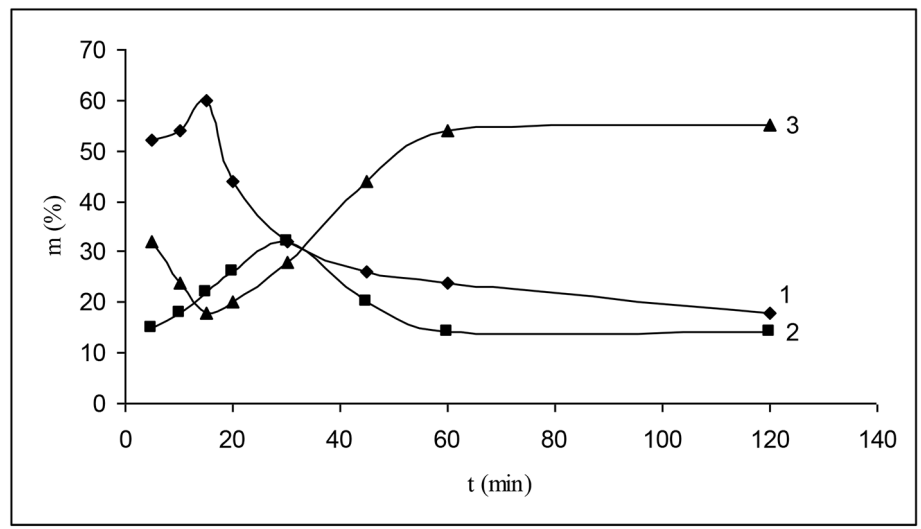

Fig. 3. Change of the dispersion composition of OV obtained by interaction between flakes and nitric acid (fraction $0.50-0.40 \mathrm{~mm}$ ) depending on the duration of the interaction. Curve $1-\mathrm{OV}$ fraction with size $0.80-0.50 \mathrm{~mm}$; Curve $2-$ OV fraction with size $0.50-0.40 \mathrm{~mm}$; Curve 3 - OV fraction with particle size smaller than $0.40 \mathrm{~mm}$ 
slowed down while the structuring processes (curves 1 and 2) became stronger. The particles with sizes smaller than $0.40 \mathrm{~mm}$ agglomerate thus entering the fraction with size $0.50-0.40 \mathrm{~mm}$ which, in turn, agglomerate into bigger aggregates (the mass of the fraction with size smaller than $0.50 \mathrm{~mm}$ increases). It means that until that moment, the structuring process prevailing over the destructive ones. By the further interaction until $30^{\text {th }}$ minute, the mass of the fraction with particle size smaller than $0.50 \mathrm{~mm}$ decreased at the expense of the increasing masses of the fractions with particle sizes $0.50-0.40 \mathrm{~mm}$ and smaller than $0.40 \mathrm{~mm}$. These results indicate that the destructive process prevails over the structuring one. After 30 min of interaction, the destructive process which results in breakdown of the aggregates enhanced to significantly higher extent - the mass of the particles with sizes smaller than $0.40 \mathrm{~mm}$ increased to reach $60 \%$. Simultaneously, the masses of the particles sized smaller than $0.50 \mathrm{~mm}$ and $0.50-0.40 \mathrm{~mm}$ decreased to about $15 \%$ during the consequent $120 \mathrm{~min}$ of the interaction.

The results obtained by sieve analysis of the oxidized vulcanizate obtained by interaction of fraction of flake with particle size $0.40-0.25 \mathrm{~mm}$ with nitric acid are presented in Fig. 4 . As can be seen from the figure, the structuring process is the dominant one during the first $30 \mathrm{~min}$. Curve 1 in the figure which illustrates the particles agglomeration is increasing. Simultaneously, curve 2 which shows the mass of the fractions of OV with particle size $0.40-0.25 \mathrm{~mm}$ is constantly decreasing. In this period of time and under these conditions, the destructive process is weaker (curve 3). At longer interaction periods o $60 \mathrm{~min}$, agglomerate breakdown became the dominant process. The mass of the fraction with particle size higher than $0.40 \mathrm{~mm}$ decreased (curve 1) while that of fraction $0.40-0.25 \mathrm{~mm}$ increased (curve 2). At the same time, a small increase of the mass of with particle size smaller than $0.25 \mathrm{~mm}$ was observed (up to $20 \%$, curve 3 ) which indicates that the destruction of the agglomerates results in formation of even smaller particles. By the interaction of the flakes with nitric acid from 60 to $120 \mathrm{~min}$, no significant change of the curves' shape was observed.

Summarizing the results presented in Fig. 2-4, it can be seen that the intensity of the destructive and structuring processes strongly depends on the fraction composition of the initial components. For flakes of fraction $0.80-0.63 \mathrm{~mm}$, the destructive process is the dominant one during the first period of interaction with nitric acid but its intensity gradually decreased while the structuring process became

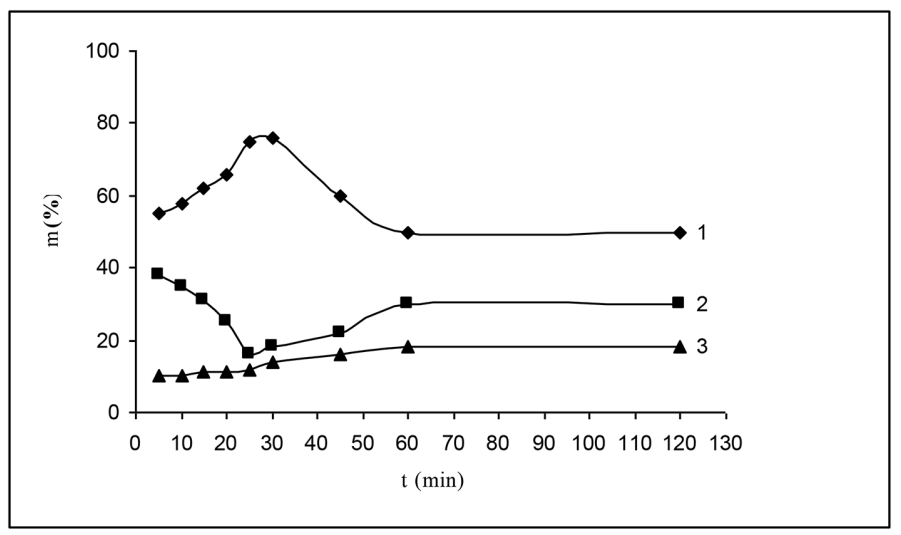

Fig. 4. Change of the dispersion composition of OV obtained by interaction of flakes with nitric acid (fraction $0.40-0.25 \mathrm{~mm}$ ) depending on the duration of the interaction. Curve $1-\mathrm{OV}$ fraction with size $0.63-0.40 \mathrm{~mm}$; Curve $2-$ OV fraction with size $0.40-0.25 \mathrm{~mm}$; Curve 3 - OV fraction with size smaller than $0.25 \mathrm{~mm}$ 
more intense. For flakes of fraction $0.40-0.25 \mathrm{~mm}$ which are characterized by significantly higher surface area at the initial moments of its interaction with nitric acid, the structuring processes are definitely the dominant ones which gradually decrease by intensity but anyway remain dominant until the end of the reaction time $(120 \mathrm{~min})$. After $60 \mathrm{~min}$ of interaction, the percent part of the three OV fractions (Fig. 2-4) remained the same.

The results obtained from the extraction of individual fractions of OV with acetone and hexane indicated that the rubber component in the vulcanizate had undergone deep structural changes which lead to the formation of polyfunctional products.

Fig. 5 sows the spectra of hexane and acetone extracts of $O V$ with particle size up to $0.80 \mathrm{~mm}$ obtained from initial flakes of fraction $0.80-0.63 \mathrm{~mm}$. In both spectra, the functional groups characteristic for
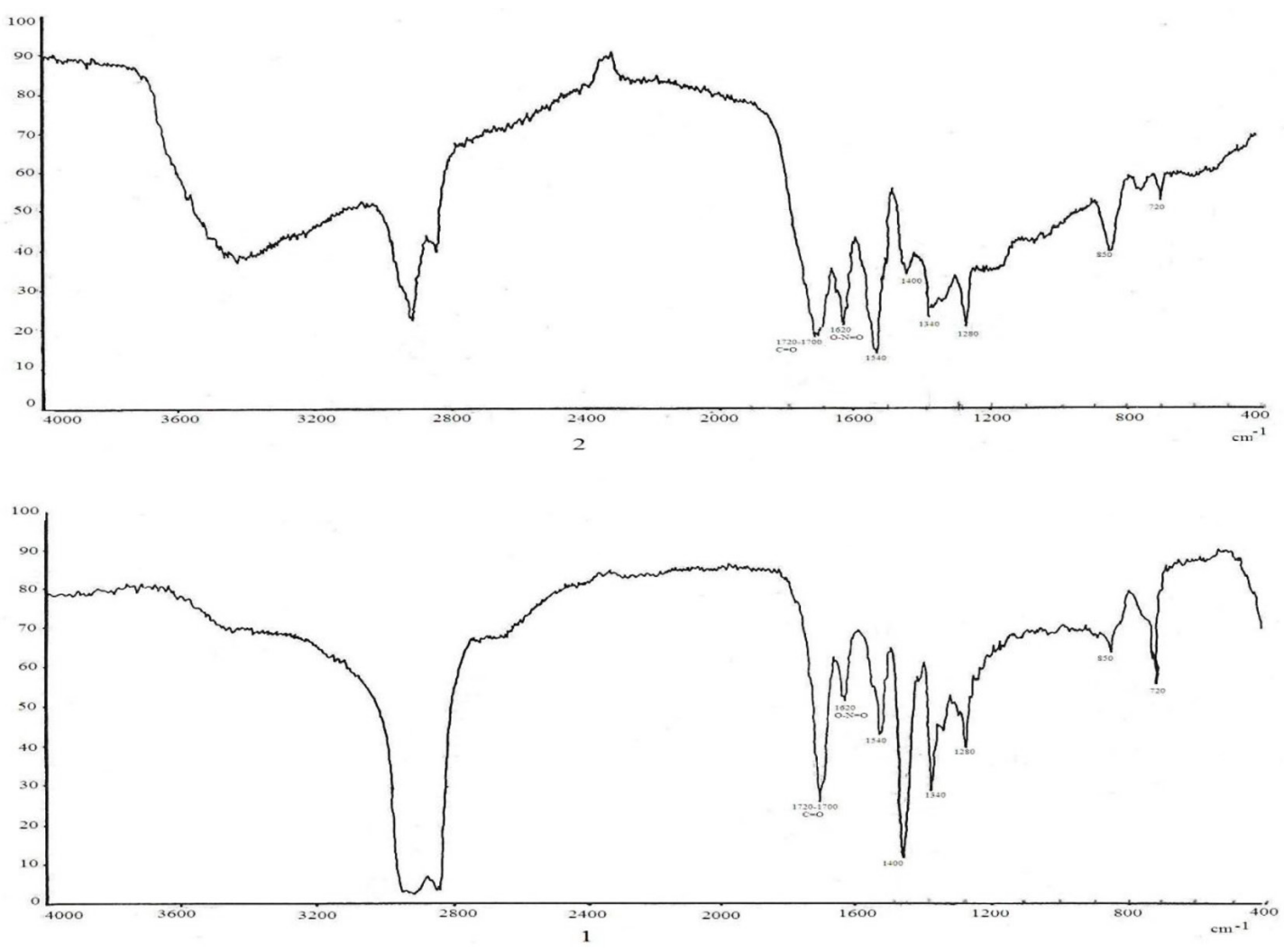

Fig. 5

these products are present: carbonyl group $1750 \mathrm{~cm}^{-1}$, nitrate-ester group at $1630 \mathrm{~cm}^{-1}$, antisymmetric and symmetric valent vibration of the nitro group at $1540 \mathrm{~cm}^{-1}$ and $1380 \mathrm{~cm}^{-1}$.

It is interesting to note that in the spectrum of the acetone extract (spectrum 2) the maximum of the absorption corresponding to the nitro group had intensity higher than that corresponding to the carbonyl group. In the spectrum of the hexane extract (spectrum 1), the ratio of the intensities of these two bands was the opposite. It means that the hexane extract was obtained from a product which was at earlier stage of the oxidative destruction of the rubber component. 


\section{Conclusion}

1. The following conclusions can be made on the basis of the results obtained.

2. The interaction between nitric acid and flakes of waste tyres characterized by relatively monodispersed nature leads to the formation of oxidized vulcanizate (OV) with polydispersed granulometric composition.

3. It was proved that the polydispersed composition of the oxidized vulcanizate is a result of simultaneous processes of destruction and structuring. The dominance of one process over the other strongly depends on the contact surface of the particles, temperature and the amount of oxidizer.

4. The rubber component of the vulcanizates undergoes deep structural changes leading to the formation of products characterized by chemical heterogeneity.

\section{References / Список литературы}

[1] Tsaikova S., Bojadjiev N., Bajdarov D. Die Angevengte makromolekulare chemie, 1986, 1391, $39-48$.

[2] Цайкова С., Бояджиев Н., Младенов И. Журнал прикладной химии, 1985, 11, 2592 2595. [Tsaikova S., Boiadjiev N., Mladenov I. Journal of Applied Chemistry, 1985, 11, 2592-2595. (in Russian)]

[3] Цайкова С. Международна конференция “Каучук и резина”, Москва, 27.09-01.10, 1994, 3, 671-680. [Tsaikova S. International Conference „Rubber and Retsina“, 27.09-01.10, 1994, 3, 671680. (in Russian)]

[4] Димов М. Взаимодействие на отпадъчни протекторни вулканизати с азотна киселина. XXVII Междунарадна научна конференция, Наука и Технологии, 1-2 юни 2017, Ст. Загора. [Dimov M. Interaction of nitric acid with rubber chunks derived from waste tires, on-line journal, «Science and Technologies» Publisher «Union of Scientists - Stara Zagora», VII, number 3, 2017, Natural and Mathematical science, 137-141 (in Bulgaria)]

[5] Милен Димов, Иван Димов, Ира Танеева. Фракционен Състав на Окислен Вулканизат и Изследване на Възможностите за Приложение на Някои Негови Екстракти. XXVIII Междунарадна научна конференция, Наука и Технологии, 31 май - 1 юни 2018, Ст. Загора. [online journal, «Science and Technologies» Publisher «Union of Scientists - Stara Zagora», VIII, 3, 2018, Natural and Mathematical science, 62-69. (in Bulgaria)].

[6] Милен Димов. Съвременен начин за оползотворяване на гумени отпадъци. Международна научна конференция - управление и образование, VIII (4), 2012, 173-176, гр. Бургас, у-т “Проф. д-р Асен Златаров". [Milen Dimov. Contemporary method for utilization of rubber wastes. Management and Education, VIII (4), 2012, 173-176, Burgas (in Bulgaria)].

[7] Авторско свидетелство, № 20483, Болгария. [Inventor’s Certificatein No. 20483 (in Bulgaria)].

[8] Генов Г., Младенов Ив. Юбелейна научна сесия на ВХТИ. Бургас, 4-6.10.1974. Болгария. [Genov G., Mladenov Iv. Anniversary Scientific session of Higher Chemistry Technological Institute. Burgas, 4-6.10.1974. (in Bulgaria)]

[9] Dimov M., Stoeva S., Tsaikova S. Interaction of Nitric Acid with Rubber Chunks Derived From Waste Tires. Oxidation Communications, 2008. 31 (4), 931-941.

$$
-213-
$$


[10] Цайкова С., Бояджиев Н.. Известия высших учебных заведений, 30 (1), 1987, 98-102. [Tsaikova S., Boiadjiev N. Izvestiya Vysshikh Uchebnykh Zavedenii, 30 (1), 1987, 98-102. (in Russian)]

[11] Цайкова С., Баяджиев Н. Азербаджанский химический журнал, 1986, 1, 54-56. [Tsaikova S., Boiadjiev N. Azerbaijani chemical journal, 1986, 1, 54-56. (in Russian)] 